\title{
Design Platform Financial Aggregator in Agriculture
}

\author{
Arsi Amallah Binhaq \\ Information System and \\ Technology \\ Institut Teknologi Bandung \\ Bandung, Indonesia \\ arsiamallah2@gmail.com
}

\begin{abstract}
Investment in agriculture is an important factor to increase country's revenue. At this time, investment in agriculture was decreased because of low interest from investor to join the agriculture project. This problem can be minimized by giving some information that relevant with investor's need. Financial Aggregator is the one paradigm for collecting data to get some insight for financial transaction. This paradigm supported by technique called web scraping. Concept financial aggregator can be delivered by designing platform that contain accurate information for investor and farmer to increase their productivity especially in agriculture project. This platform will give analysis data of some agriculture startup and transform it into information that help investor to choose best investment in agriculture.
\end{abstract}

Keywords—investment, platform, financial, aggregator, agriculture

Article history:

Received: 12 March 2019 Received in revised form: 20 March 2019 Accepted: 12 April 2019 Available online: April 2019

\section{INTRODUCTION}

Indonesia has big potential that given to manage their own land. Half of total land in Indonesia assigned to agricultural purpose. This fact covered 94 million hectares of Indonesia's land used by farmer to product some variation agriculture product. At this time, conversion agriculture's land to another industry was increased. The main factor that increase this fact is low attraction from investor and lack of education from farmer. From investor perspective, they felt that join agriculture project was not safe. Investor lack of believe that management in that production was professional. Another perspective from farmers, they felt that their agriculture production is low. Farmers can't get some education from master in that sector, because of that they still use conventional method for producing agriculture commodities. One of technology that can be used to cope this problem is financial technology. Term 'financial technology' defined as combination of financial services and technology to increase effectivity and efficiency of financial transactions. Financial technology grew in Indonesia as payment be the first top category that have applied at some institutions [1]. One of financial technology category that has low interest is aggregator. Financial aggregator is the one solution for agriculture industry to minimize risk of investment and give some information needed by stakeholder.

\section{LITERATURE STUDY}

\section{A. Platform}

Platform is new product that used to fulfill customer's need, but the platform's design easy to change into derivative by adding, substitution, or reducing feature of system [2]. In another perspective, platform defined as a place that have technology base with some addons can interoperate, following standards and allowing for transactions amongst stakeholders, within the platform-centric ecosystem [3]. Platform also defined as a vendor product, architecture system standard, or communication protocol. From technological perspective, platform can be a mobile operating system or applications; even it desktop 
based, website based or device based [4]. In easy term platform can be defined as place with technology base which allows built on an application or another component to reach a straight goal. There are three categories of platform mentioned by QuickBooks [5].

1. Peer to Peer Platform

This concept allows system user can interact with other directly inside ecosystem. One example of this concept is transaction held by marketplace. In this case, user can communicate and do some transactions with another user inside ecosystem.

2. Platform for Third Party Developers

This concept allows third party developers build applications related with platform's goal. One example of this concept is providing application programming interface (API) to another developer as a tool to develop main system better.

3. Platform for Third Party Services or Products

This concept allows data of customer used by third party as a transformation to give relevant information to increase quality of service.

\section{B. Financial Aggregator}

Financial Aggregator defined as bundling of small project group to reach a scale where they become attractive to large investors, for investment, on-sale or for securitization through issuing a bond [6]. Another definition of financial aggregator is any mechanism that aggregates capital around particular characteristics of investments [6]. The challenge that can be solved by financial aggregator are:

1. Reduce risk and cost of financial transaction

Use of financial aggregator allows collection data of project's risk, company's asset, and provide services based on data collected to help investor choose their best investment.

2. Find best price of financial product

Another benefit of using financial aggregator is helping user to find best negotiation of their transaction. User using information from transformation data before to get some insight in order to choose best product.

3. Reduce barriers that happens at market

Use of financial aggregator can remove or reduce barriers that happens at market especially related to risk of project such as policy, tax, and regulation issues, or increased cost. The main factor that help user to cut the barrier is information that given by system. This information provides facts to argue all policy that can harm many stakeholders in that market.

Business model of financial aggregator can be drawn at figure 1 .

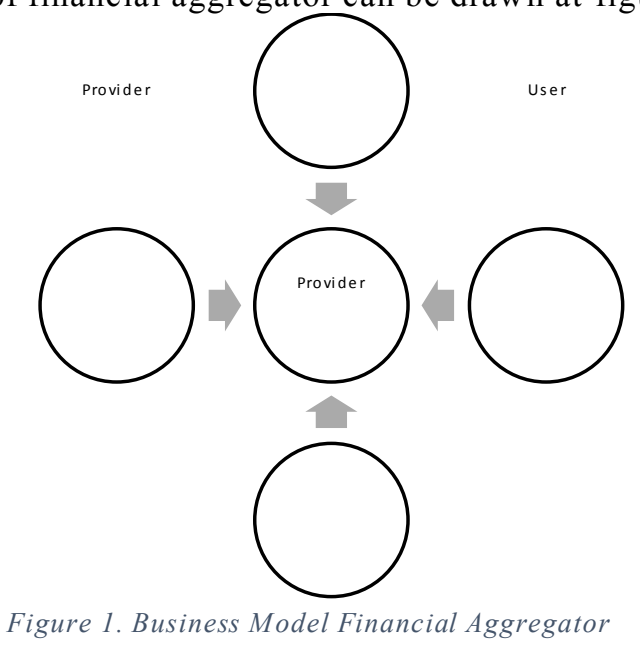

Aggregator collected data from many providers and transform it into useful information that can used by user as their knowledge of financial transaction. This aggregator reduce s 
risk of failure investment or bad product. User can minimize their worries into good decision of financial product.

\section{Financial Technology (FinTech)}

FinTech defined as new emerging company that changes people paradigm about payment, send money, lend money, and investment [7]. Another definition of fintech is group of computer program and another technology to support financial services [8]. Fintech also defined as industry arranged by technology company based to run financial function and provide financial services efficiently [9]. There are four main categories of fintech that spread in Indonesia [1].

1. Deposit, Lending, and Capital Raising According to the website Investopedia, the deposit is a transaction involving the transfer of funds to other parties for activities safely store money or funds used as collateral for the delivery of goods [10]. According to the website thebalance.com, lending is giving money or property to a borrower that is temporary in the hope that borrowers will return to the lender [11]. According to the website cleverism.com, raising capital is the individual's ability to obtain financing in order to be able to help businesses grow and daily operations [12]. Some fintech concept that fits this category is crowdfunding and peer to peer lending

2. Market Provisioning

According Kusumadewi in teknologi.id, provisioning market is the provision of a variety of information to help people find the best financial products and provides free access to a wide range of financial products that allow users to take financial decision [13]. One example of this category is a e-aggregator.

3. Payment, Clearing, and Settlement

According to David Medeiros, Clearing and settlement is an interbank process that has regulations from the banking authorities and the state. The efficiency of its operations is determined by the policies and systems that will be used to help process the payment that is clean and comfortable [14]. Examples of concepts that fall into this category are mobile payment, web-based payment, and digital currency

4. Investment and Risk Management

Investment and Risk Management is a way to manage a risk from investments made

[1]. Examples of fintech concepts included in this category are robo advice, etrading, and insurance.

Benefit of using FinTech can be described as below.

1. Increase user experience from easy to access information, easy to display data transparent, easy to open account, and add understanding of transaction.

2. Increase choice of product, increase product quality, and minimize product price with variant product choice [9].

3. Encourage export skill small micro finance

4. Encourage equity welfare

5. Increase national finance inclusion

6. Encourage distribution of national payment

7. Help fulfillment domestic payment [1].

Financial technology has advantage and disadvantage at same time. There are some disadvantages and risks using financial technology.

1. Untested credit modeling risk that raises doubts for investors and business actors.

2. Risk of adjusting business models with existing financial actors such as banks, other financial institutions.

3. Operational risks that cannot be applied to all elements involved.

4. The risk of data leakage due to data management that is not in accordance with security standards [9].

5. Risk of misuse of funds due to the speedy processing of transactions with FinTech. 
6. Risk of disrupting existing financial system stability [2].

\section{Risk in Agriculture Investment}

The implementation of investment both conventional and sharia will involve various kinds of problems. The following are some of the risks that might arise related to agricultural investment activities.

1. Agricultural weather is unpredictable, causing other diseases or disorders. This factor has an impact on the use of drugs to prevent and to treat the disease.

2. Selling prices of agricultural products that are not in accordance with farmer's predictions and platforms. Factors that influence the incompatibility of agricultural selling price predictions are as follows.

a. Farmer in the same area got larger harvest that increases commodities and commodity prices will decline.

b. There are government subsidies which reduce market prices.

c. Pressure from local distributor who control the area.

d. Plants that are susceptible to disease cause the possibility of no harvest.

3. Force majeure occurs that cannot be predicted and prevented by all parties such as floods, landslides, fires and various other natural activities [15].

\section{E. Web Scraping}

Web scraping is a technique used to collect and format various forms of data from the internet [16]. In certain web structures, there are inaccuracies in the visualization of data so the information that can be absorbed by users is reduced, web scraping appears as an alternative that is used to visualize data and provide more structured information so that users can get more accurate information. The development of web scraping influenced by the need for more effective and efficient data usage by certain business entities, therefore the development of web scraping is in line with the development of business intelligence. The following will present one of the new approaches to developing web scraping that has been combined by (Milev,2017) based on research on the close relationship of software development with business intelligence [16].

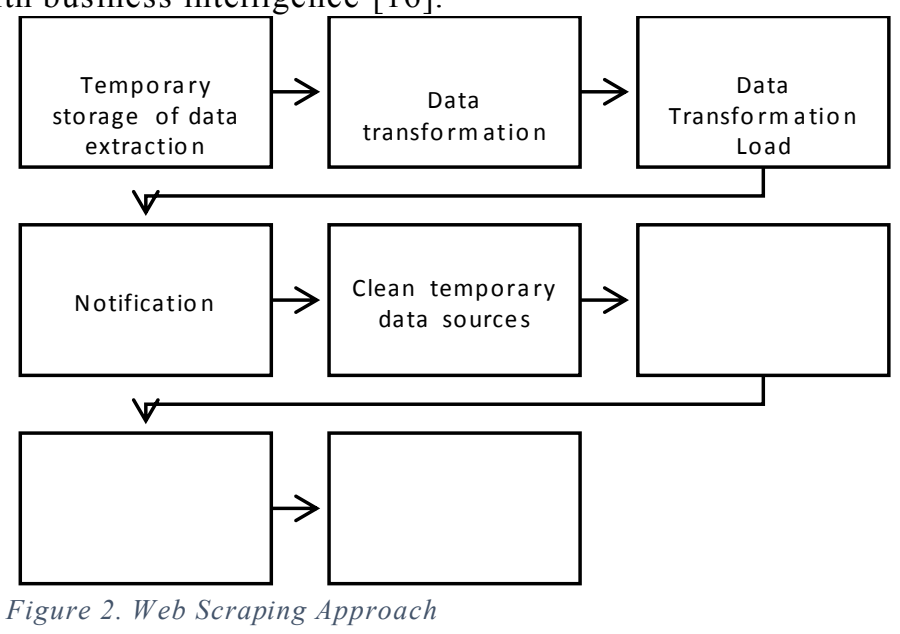

The step of developing application web based showed by figure 2. First, to get data that suits the goal, it's needed to define data sources will be use in extraction process from another website. After define data sources, the next step is doing analysis of data sources by opportunity of getting data from that sources. The next step is data extraction to get data from original sources and store it into temporary file. Stored data in temporary file will be transformed into information that relevant with main goal system and load it into data warehouse. After that, the system update and search data they needed. The last step is cleaning temporary data sources that used at web scraping process [16]. 
Scarping web is divided into two main categories: web scraping by coding and web scraping by automated API. The following are differences between two types of web scraping technique.

1. Web scraping by coding

This technique facilitates the customization process of web scraping. The main benefit using this technique are flexibility and customization. Developers can build their own script to get data from external sources to reach the goal. The disadvantage using this technique are needing to understand programming, needing to adapt change of web structure, and sometimes request is rejected by external sources.

2. Web scraping by created automated API

This technique was created to facilitate user who never learn programming to get data for their own goal. The benefit of using this technique are easy to use and using standard data format to share data. But there are disadvantages such as not flexible for customizing structure data and need to subscribe to get first tier feature [17].

\section{ANALYSIS AND DESIGN SYSTEM}

\section{A. Problem}

Problem that occur when developing platform financial aggregator in agriculture can be seen from various perspectives. Problem identification modeled by ishikawa diagram as follows. The main problem that occur in this paper is low attraction of agriculture investment.

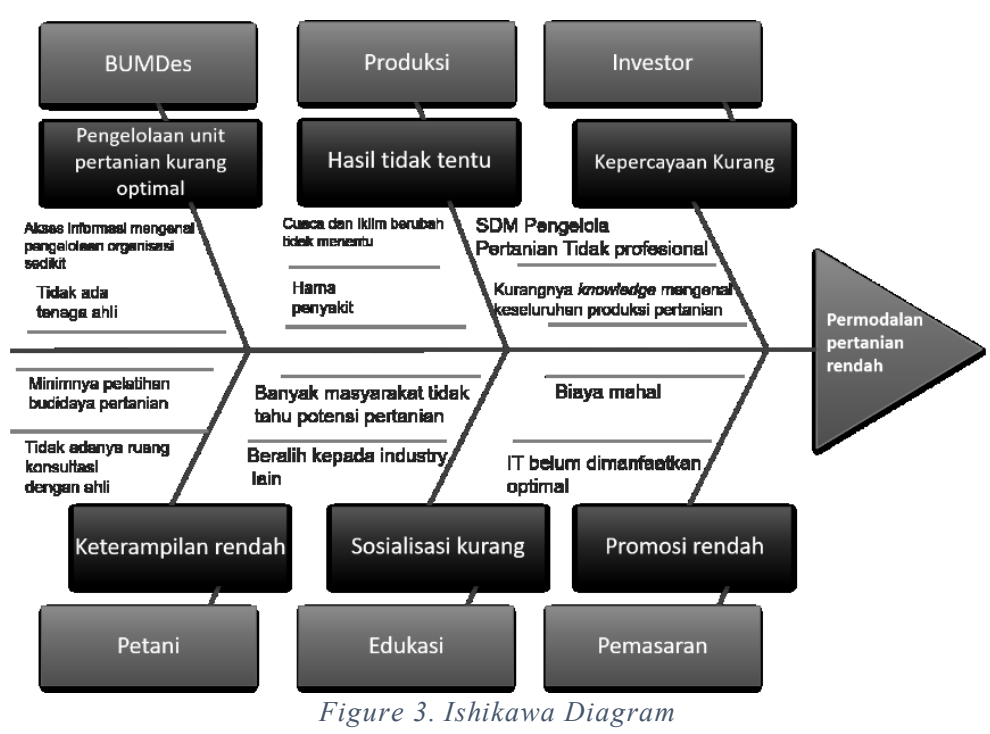

This is the details of figure 3 to describe various perspective of main problem in agriculture.

1. Investor

Investor do not have trust in agricultural management. This factor results in a lack of investment interest. Another factor that encourage investor do not join agricultural investment is lack of relevant information that can secure their money.

2. Production

As explained before at literature study about risk of agriculture investment, production in agriculture industry influenced by weather and disease. This results in uncertain production.

3. BUMDes

BUMDes is a business unit that manages village assets for the welfare of community. One of their assets can be agriculture product, but their management 
lack of knowledge and cause some problem to unit. This results in decline of investor interest to join their project.

4. Marketing

Low capital is also caused by the lack of massive marketing from the agricultural manager. One of the root causes of the problem is the high marketing costs and the lack of utilization of information technology resources in distributing agricultural projects.

5. Education

Public education on agricultural production is lacking so that people are less interested in plunging or just looking at agricultural projects. In addition, lack of information on effective and efficient agricultural production processes also encourages farmers to sell agricultural land to other industries.

6. Farmers

The problem that occurs from the farmer's point of view is the lack of training in the management of agricultural production or the right method of conducting agricultural production efficiently and effectively.

\section{B. Opportunity}

Opportunities that can be identified as alternative solutions to the problems faced are as follows.

Table 1. Opportunities of solving problems

\begin{tabular}{|l|l|}
\hline No & Opportunities \\
\hline 1 & $\begin{array}{l}\text { Creating services that are able to integrate channeling of investor funds for operational needs } \\
\text { of agricultural production. }\end{array}$ \\
\hline 2 & Utilizing information technology to support investor and farmer integration services \\
\hline 3 & Use a web aggregator to compare agricultural investment products \\
\hline 4 & Strengthen promotion and education of agricultural production through social media \\
\hline 5 & Utilizing business intelligence technology to help manage knowledge on BUMDes \\
\hline
\end{tabular}

\section{Stakeholder Analysis}

Stakeholders are those who have a role in the financial aggregator platform system activities. The following is a breakdown of stakeholders and the roles they have in the system.

Table 2. Stakeholder analysis

\begin{tabular}{|c|l|l|}
\hline No & \multicolumn{1}{|c|}{ Stakeholder } & \multicolumn{1}{c|}{ Roles } \\
\hline 1 & Investor & $\begin{array}{l}\text { Review agricultural investments based on information provided by the } \\
\text { system }\end{array}$ \\
\hline 2 & Petani & $\begin{array}{l}\text { Looking at grain and commodity price data as a reference for selling } \\
\text { agricultural production }\end{array}$ \\
\hline 3 & Pemerintah & $\begin{array}{l}\text { Determine agricultural policies based on information provided by the } \\
\text { system }\end{array}$ \\
\hline 4 & $\begin{array}{l}\text { Perusahaan } \\
\text { Pertanian }\end{array}$ & Investasi \\
\hline
\end{tabular}

\section{User Requirements}

Based on the analysis of problems and opportunities that have been done before, it can be concluded that there are five main business needs that must be met. There are the lists of user requirements.

Table 3. User Requirements

\begin{tabular}{|l|l|}
\hline \multicolumn{1}{|c|}{ Code } & User Requirements \\
\hline UR001 & Users can view agricultural projects from trusted sources \\
\hline UR002 & Users can compare agricultural projects \\
\hline
\end{tabular}




\begin{tabular}{|l|l|}
\hline UR003 & Users can view fund analysis and agricultural investment trends \\
\hline UR004 & Users can view commodity price data \\
\hline UR005 & Users can ask farm questions in the forum \\
\hline
\end{tabular}

\section{E. Functional Requirements}

Based on the list of needs mentioned in user requirements, the following are functional requirements that exist in the system.

Table 4. Functional Requirements

\begin{tabular}{|l|l|}
\hline \multicolumn{1}{|c|}{ Code } & \multicolumn{1}{c|}{ Functional Requirem ents } \\
\hline FR001 & The system can display agricultural investment projects from several trusted sources \\
\hline FR002 & The system can compare agricultural investment projects \\
\hline FR003 & The system can display a chart in the form of an analysis of agricultural investment data \\
\hline FR004 & The system can display agricultural commodity price data \\
\hline FR005 & The system can display agricultural question and answer forums \\
\hline
\end{tabular}

\section{F. Use Case Diagram}

According to (Miles \& Hamilton, 2006), a use case diagram is a diagram that shows what the system must do, so that it can meet the needs of users [18]. The use case diagram of the system to be created can be seen in Figure 4.

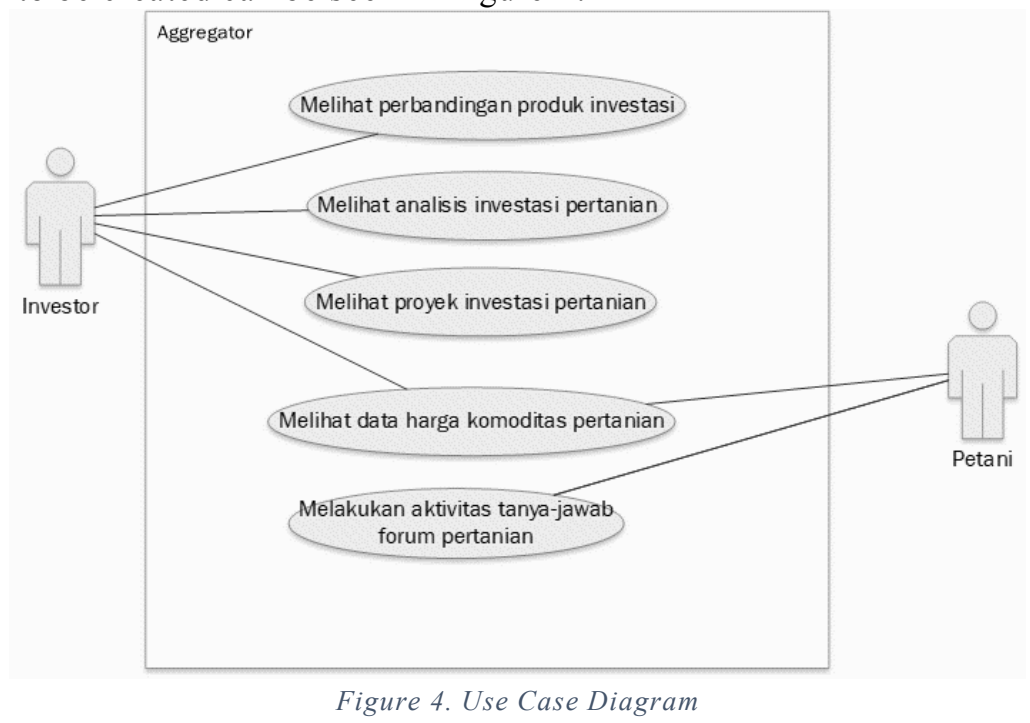

In the picture above, there are two categories of actors in the use case diagram, namely farmers and investors. Farmers will carry out activities to see agricultural commodity price data, especially grain prices or selling prices of agricultural products at the distributor level. In addition, farmers are also able to carry out question and answer activities at an agricultural forum to provide insight into more optimal methods of managing agricultural production. Investors carry out three main activities in order to reduce the risk of investment that will be carried out by looking at a comparison of investment products, looking at the analysis of investment product data, and looking at reference prices for agricultural commodities.

\section{G. Activity Diagram}

According to (Miles \& Hamilton, 2006), activity diagrams are diagrams that illustrate the way the system reaches its goals. This diagram shows the high-level actions that are combined in order to represent the processes that occur in the system [18]. The activity diagram of the system to be created can be seen in Figure 5. 


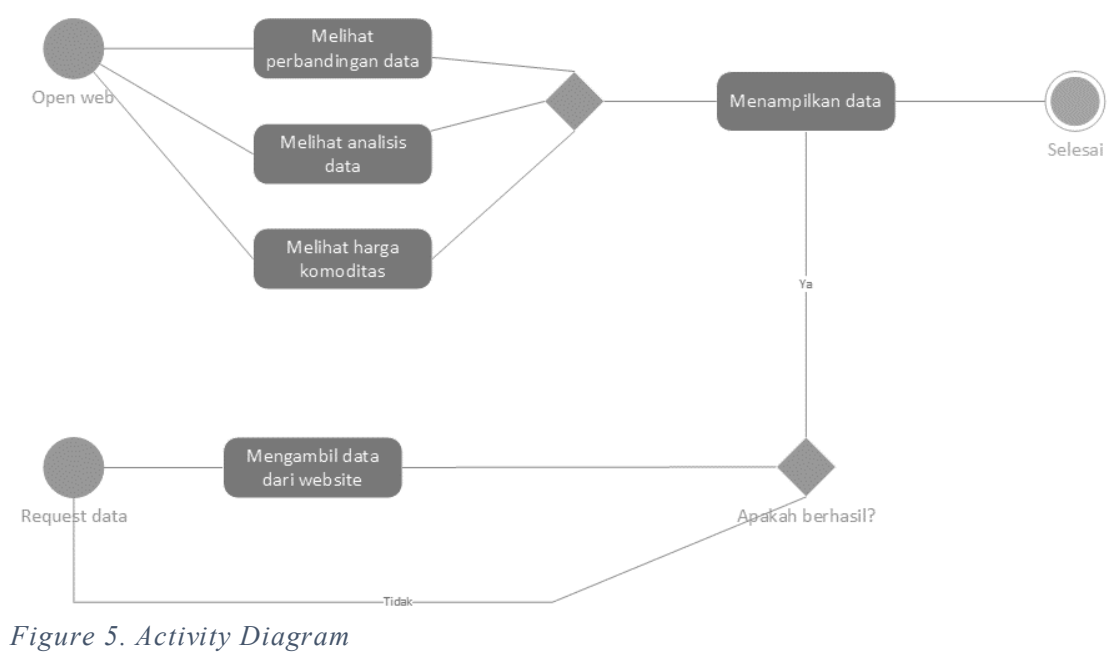

The activity diagram shows the processes that occur in the system. The platform will request from an external data source using the selected tool. If the request is successfully carried out, then the data will be temporarily stored in the format chosen (CSV or JSON). Then the data that has been obtained will be displayed on the main page of the system in the form of a chart of agricultural project data analysis, comparison of agricultural projects, commodity prices, and the existence of a question and answer forum.

\section{RESULTS AND TESTING}

\section{A. System Implementation Environment}

The system implementation environment is carried out on hardware and software. The following is an environmental table for implementing an agricultural investment aggregator.

1. Software

Table 5. Software Environment

\begin{tabular}{|l|l|l|}
\hline No & Component & Information \\
\hline 1 & Operating System & Windows 10 Education version \\
\hline 2 & Hosting & 000webhost \\
\hline 3 & Programming Language & JavaScript, HTML \\
\hline 4 & Framework & Bootstrap 3.3.5, Highcharts, ChartJS 2.4.0 \\
\hline 5 & Parsing Tools & Parsehub free edition, Octoparse free edition \\
\hline 6 & Browser & Google Chrome 72 \\
\hline 7 & Local Hosting & XAMPP v.3.2.2 \\
\hline
\end{tabular}

2. Hardware

Table 6. Hardware Environment

\begin{tabular}{|l|l|l|}
\hline No & Component & Information \\
\hline 1 & CPU & Intel Core i5-7200U @ 2.50 GHz \\
\hline 2 & RAM & $8 \mathrm{~GB}$ \\
\hline 3 & System Type & $64 \mathrm{bit}$ \\
\hline 4 & VGA Card & Nvidia GeForce 940MX (2GB) \\
\hline
\end{tabular}

\section{B. Implementation of Application}

Implementation of the application on this system is divided into two parts interface pages. The first page is the implementation of the main page of the system that se rves to display investment project information, displays information on agricultural investment data analysis, and displays the prices of food commodities. The second page displays the results of comparison of agricultural investment projects based on certain criteria. There is farmer forum page for asking some questions and sharing information of agriculture. 


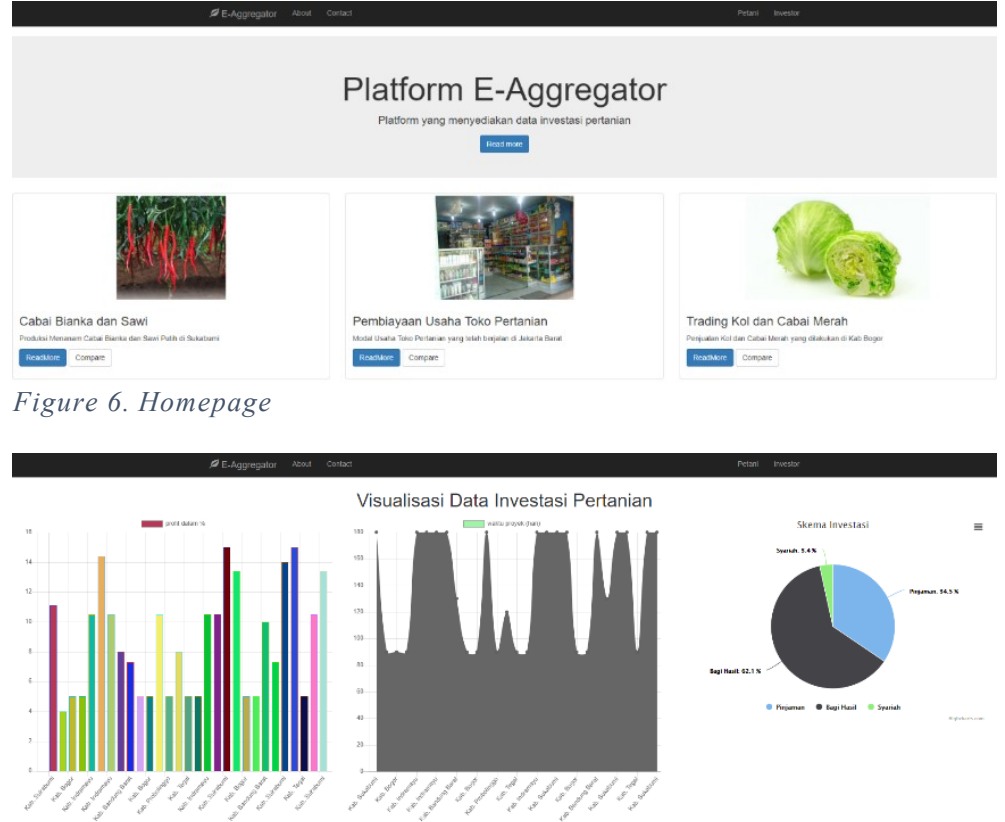

Figure 7. Data Visualization

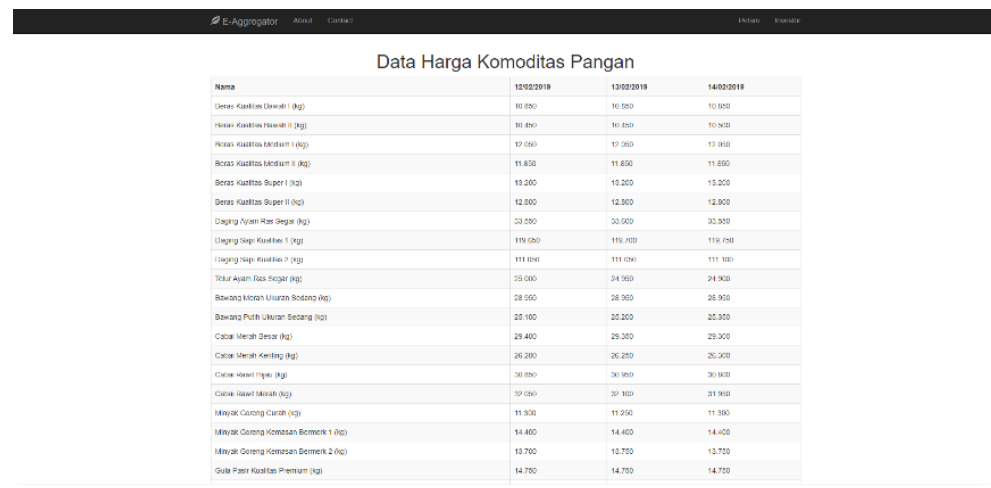

Figure 8. Table Commodity Price

Projects Comparison Table

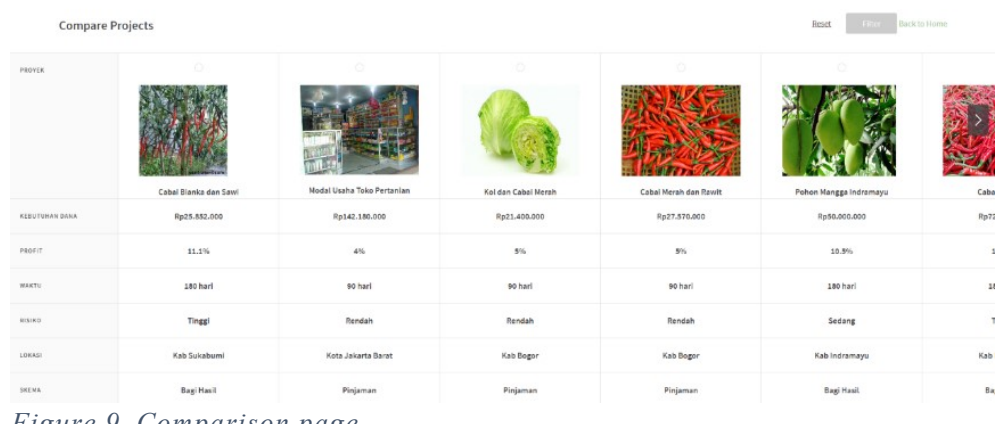

Figure 9. Comparison page 


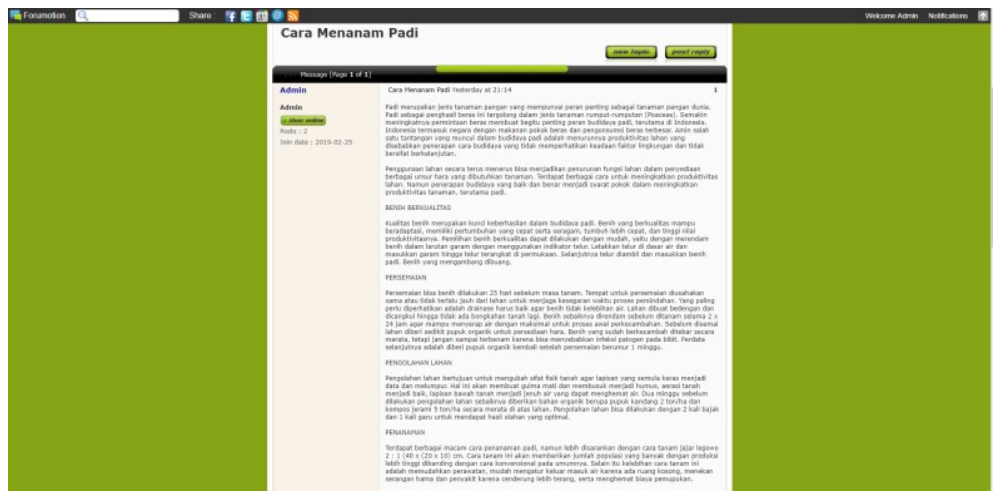

Figure 10. Farmer Forum

\section{Testing}

After performing the implementation stage, the next step is testing the system. The system testing method that is carried out is black box, which is testing the system based on observations of test results and functional systems.

Table 7. Application Testing

\begin{tabular}{|c|c|c|c|c|c|}
\hline ID & $\begin{array}{l}\text { Functional } \\
\text { Requirements }\end{array}$ & Test Case & Description & Parameter & Result \\
\hline $\begin{array}{l}\text { SPA- } \\
01\end{array}$ & $\begin{array}{l}\text { The system can } \\
\text { display agricultural } \\
\text { investment projects } \\
\text { from several trusted } \\
\text { sources }\end{array}$ & $\begin{array}{l}\text { Test the program } \\
\text { code } \\
\text { displaying the main } \\
\text { page }\end{array}$ & $\begin{array}{l}\text { The browser can } \\
\text { display agricultural } \\
\text { investment projects } \\
\text { that have been taken } \\
\text { from several trusted } \\
\text { sources }\end{array}$ & $\begin{array}{l}\text { Data } \\
\text { availability } \\
\text { and accuracy }\end{array}$ & Success \\
\hline $\begin{array}{l}\text { SPA- } \\
02\end{array}$ & $\begin{array}{l}\text { The system can } \\
\text { compare } \\
\text { agricultural } \\
\text { investment projects }\end{array}$ & $\begin{array}{l}\text { Test the program } \\
\text { code to make } \\
\text { comparisons } \\
\text { between agricultural } \\
\text { investment projects }\end{array}$ & $\begin{array}{l}\text { The browser can } \\
\text { display a table of } \\
\text { comparisons between } \\
\text { available agricultural } \\
\text { investment projects }\end{array}$ & Availability & Success \\
\hline $\begin{array}{l}\text { SPA- } \\
03\end{array}$ & $\begin{array}{l}\text { The system can } \\
\text { display a chart in } \\
\text { the form of an } \\
\text { analysis } \\
\text { agricultural of } \\
\text { investment data }\end{array}$ & $\begin{array}{lr}\text { Test the program } \\
\text { code to display } \\
\text { charts as } \\
\text { visualization } \\
\text { processed of } \\
\text { analysis } \\
\text { agricultural } \\
\text { investments }\end{array}$ & $\begin{array}{l}\text { The browser can } \\
\text { display charts of the } \\
\text { results of analysis of } \\
\text { agricultural } \\
\text { investment data that } \\
\text { have been obtained } \\
\text { previously }\end{array}$ & $\begin{array}{l}\text { Availability, } \\
\text { Compatibility }\end{array}$ & Success \\
\hline $\begin{array}{l}\text { SPA- } \\
04\end{array}$ & $\begin{array}{l}\text { The system can } \\
\text { display agricultural } \\
\text { commodity price } \\
\text { data }\end{array}$ & $\begin{array}{lr}\text { Test the program } \\
\text { code to display } \\
\text { agricultural } & \text { food } \\
\text { commodity } & \text { price } \\
\text { data } & \end{array}$ & $\begin{array}{l}\text { The browser can } \\
\text { display a table of } \\
\text { results of data } \\
\text { collection on } \\
\text { agricultural food } \\
\text { commodity prices }\end{array}$ & Availability & Success \\
\hline $\begin{array}{l}\text { SPA- } \\
05\end{array}$ & $\begin{array}{l}\text { The system can } \\
\text { display agricultural } \\
\text { question and } \\
\text { answer forums }\end{array}$ & $\begin{array}{l}\text { Test the program } \\
\text { code to display } \\
\text { agricultural forums }\end{array}$ & $\begin{array}{l}\text { The browser can } \\
\text { display agricultural } \\
\text { forums }\end{array}$ & Availability & Success \\
\hline
\end{tabular}

\section{Data Analysis}

Based on the results of data collection from three websites above the given data structure is different. Each website does not provide the same information, but there are criteria that always exist in each project, namely profit and time period. For funding needs, the crowde and tanifund sites provide the data, while igrow only provides sold unit data and a minimum price per unit. Based on the results of data collection, the following is a summary of information that can help investors and the government in making decisions. 
Table 8. Summary of Data Collection

\begin{tabular}{|c|c|c|c|}
\hline No & Criteria & Value & Information \\
\hline 1 & Profit & $\begin{array}{ll}\text { a. } & 7 \% \text { (crowde) } \\
\text { b. } & 15 \% \text { (igrow) } \\
\text { c. } & 17 \% \text { (tanifund) }\end{array}$ & $\begin{array}{l}\text { With the average project making } 7-17 \% \text { profit, the } \\
\text { risk category provided by investment companies is } \\
\text { at the middle-high level. The profit below } 5 \% \text { is } \\
\text { usually classified as a low risk category }\end{array}$ \\
\hline 2 & City & $\begin{array}{l}\text { Most: Kab Bogor }(25 \%) \text { dari } \\
\text { situs Crowde }\end{array}$ & $\begin{array}{l}\text { The project distribution is still centered on the } \\
\text { island of Java. Even though there is a lot of potential } \\
\text { that can be developed on Sumatra Island to Papua } \\
\text { Island. }\end{array}$ \\
\hline 3 & Period & $\begin{array}{l}\text { a. Crowde: } 118.75 \\
\text { hari } \\
\text { b. Tanifund: } 496.79 \\
\text { hari } \\
\text { c. IGrow: } 5 \text { tahun }\end{array}$ & $\begin{array}{l}\text { For funding projects, agricultural production varies } \\
\text { from short to long term. The crowde site includes } \\
\text { providers of short-term agricultural projects with } \\
\text { relatively small risks. Whereas tanifunds and igrow } \\
\text { include agricultural production service providers } \\
\text { with long-term contracts and the risk is quite high. }\end{array}$ \\
\hline 4 & Category & $\begin{array}{l}\text { Most: Agriculture } 84 \% \text { from } \\
\text { Tanifund }\end{array}$ & $\begin{array}{l}\text { The agricultural project is still a favorite for } \\
\text { business people in the village. }\end{array}$ \\
\hline 5 & Schema & $\begin{aligned} \text { a. } & \text { Crowde: Lending } \\
& (58 \%), \text { Profit-Loss } \\
& \text { sharing }(42 \%) \\
\text { b. } & \text { Tanifund: Profit- } \\
& \text { Loss sharing } 100 \% \\
\text { c. } & \text { IGrow: Profit-Loss } \\
& \text { sharing } 100 \%\end{aligned}$ & $\begin{array}{l}\text { Most of the schemes applied to the three companies } \\
\text { are monthly, end of year, yearly, and so on. }\end{array}$ \\
\hline 6 & $\begin{array}{l}\text { Fund } \\
\text { Requirement }\end{array}$ & $\begin{array}{ll}\text { a. } & \text { Crowde: } \\
\text { Rp40.313.554 } \\
\text { b. } \\
\text { Tanifund: } \\
\text { Rp766.503.571 }\end{array}$ & $\begin{array}{l}\text { Funding requirements on the crowde site are low } \\
\text { due to short project time and risk, while the funding } \\
\text { requirements on tanifunds and igrow are quite large } \\
\text { given the long project period. }\end{array}$ \\
\hline
\end{tabular}

\section{CONCLUding REMARKS}

Design of platform financial aggregator solve lack of education problem for farmer and investor by providing relevant information. This project successfully implements design of platform financial aggregator that run on website technology with main parameter is availability of feature. This design implement all of five user requirements to one platform that will be use by investor to choose agriculture investment correctly. Another benefit of this designing for investor are minimizing failure of investment by learn the information first before choosing the project.

\section{REFERENCES}

[1] Bank Indonesia, 2018, "Financial Technology Perkembangan dan Respons Kebijakan Bank Indonesia", Jakarta: Bank Indonesia FinTech Office.

[2] Gawer, A., 2009, "Platforms, Markets and Innovation", Cheltenham, UK and Northampton, US: Edward Elgar.

[3] Dal Bianco, V., et.al, 2014, "The Role of Platform Boundary Resources in Software Ecosystems: A Case Study", IEEE/IFIP Conference on Software Architecture.

[4] Sun, R., and et.al, 2015, "Information Technology Platforms: Conceptualisation and a Review of Emerging Research in IS Research", Australasian Conference on Information System: Adelaide.

[5] Hagiu, A., and J. Altman, E., 2013, "Intuit QuickBooks: From Product to Platform": Harvard Business School

[6] Shayka, C., \& Byrnes, R., 2017, "Turning Up the Volume: Financial aggregation for off-grid energy": IIED Issue Paper, London 
[7] Chisti, S., and Barberis, J., 2016, "The FINTECH Book: The Financial Technology Handbook for Investors, Entrepreneurs and Visionaries", John Wiley \& Sons Ltd: West Sussex

[8] Oxford, "fintech, n.", OED Online, Oxford University Press, URL: https://en.oxforddictionaries.com/definition/fintech. Access Time: 5 March 2018

[9] Ancri, C., 2016, "Fintech Innovation: An Overview", Board of Governors of Federal Reserve System

[10] Investopedia 2018 ,

"Deposit", URL: https://www.investopedia.com/terms/d/deposit.asp, Access Time: 5 March 2018

[11] Murray, J., 2018, What is Lending? What are the Types of Lending?, URL: https://www.thebalance.com/what-is-lending-what-are-lenders-398319. Access Time: 5 March 2018

[12] Cleverism, 2018, Capital Raising: Definition, Importance for Career, Ways to Improve, URL: https://www.cleverism.com/skills-and-tools/capital-raising-skills/. Access Time: 5 March 2018

[13] Kusumadewi, Y., 2017, Startup Fintech, Proses Keuangan Praktis, Aman dan Modern, URL: $\quad$ https://medium.com/teknologi-id/startup-fintech-proses-keuangan-praktisaman-dan-modern-9305e9ec0672. Access Time

[14] Medeiros, D., 2004, Clearing and Settlement, URL: http://www.banktech.com/payments/clearing-and-settlement-/d/did/1290019d41d.html. Access Time: 5 March 2018

[15] Crowde, Risiko Permodalan, URL: https://crowde.co/investment-risk. . Access Time: 10 March 2018

[16] Milev, P., 2017," Conceptual Approach for Development of Web Scraping Application for Tracking Information": Economic Alternatives, 2017, Issue 3, pp. 475-485.

[17] Krijnen, D., Bot, Rinus., \& Lampropoulos, G., 2014, “Automated Web Scraping APIs": Leiden University.

[18] Miles, R., \& Hamilton, K., 2006, “Learning UML 2.0”, O'Reilly 